\title{
The Use of Media in Indonesian Language Learning for SMP/MTSN Students Ummi Kultsum/19016062 \\ kultsumummi11@gmail.com
}

Indonesian language subjects are compulsory subjects at every level of education in Indonesia. Indonesian language learning is carried out starting from the elementary school, junior high school, high school, and university level. Indonesian language learning activities at each level take place in various ways. It is important for someone to understand learning Indonesian for their survival. According to Yulia et al, (2012) contextual learning is a learning activity that relates learning material to the reality of the student's world, so that students are able to make connections between their knowledge and their application in real life. All Indonesian language learning materials are expected to be applied in real life.

According to Mulyadi, et al, (2018) today's learning activities rely on skills and active learning processes. Students are required to be more active in learning that is carried out by using their skills. The main support for Indonesian language learning activities is by using learning media. Therefore, learning media is an important forum. The use of technology including media in education according to Ramadhan, et al, (2019) allows a variety of new ways to connect with others and access information about education, and has consequences in formal teaching.

According to Arsyad (in Jaya, et al, 2013) media is a tool used to convey or deliver teaching messages. Media is anything that can transmit messages, stimulate students' thoughts, feelings and desires so as to encourage the learning process to occur in them. Educational media is a set of tools or complementary used by teachers or educators in order to communicate with students or learners. These tools are called educational media, while communication is the delivery system. Hamalik (in Jaya, et al, 2013) conveyed that the use of learning media in the teaching and learning process can generate motivation and stimulate students as in the psychological realm and student understanding.

Ramadhan, et al, (2019) mentions that media allows students to interact in the most modern and innovative ways but not too formally in educational activities. Ease of accessing technology makes it easy to use media. Of course this affects education. According to Javorsky (in Ramadhan, et al, 2019) education must reflect real change and consider various ways that can support the demand to provide quality conditions for human existence in the context of social transformation processes. With the ease of technology in accessing media, the realization of changes for the better for the world of education can be realized.

However, behind the ease of learning through media, there are facts on the ground that the use of learning media is not optimal. According to Novelti, et al, (2018) teachers rarely use multimedia in learning, thus making students less enthusiastic in learning. Teachers do not do innovative learning such as using various media to make students motivated in the learning process. Likewise, the limited ability of Indonesian language teachers to use learning media, plus teachers often come in late, and let students leave class, this makes learning less meaningful and not in accordance with learning objectives.

Apart from that, there are various types of learning media. ranging from media to hardware and software. The entire media used serves as a support for learning activities. Part of the software and hardware is also divided into various kinds such as audio media, image or visual media, audiovisual media, video and so on.

An example of media for learning Indonesian is picture media. According to Fitri, et al, (2016) picture media is one of the techniques in learning that can be used as a variation in 
writing skills. Image media is one of the most basic forms of communication media. Pictures don't just serve as entertainment. But more than that, images have a very large function. One of these is conveying ideas to others, as well as respect and several other benefits. In addition, Subana and Sunarti (in Fitri, et al, 2016) state that images are imitations of goods (people, animals, plants, and so on). The image becomes a two-dimensional visual medium on a nontransparent field. Pictures can be used by teachers as a place to provide explanations so that they are more concrete than if they were only described in words. Through pictures, teachers can translate abstract ideas into a more realistic form.

Image media has its own types, for example serial images. According to Hizati, et al, (2018), serial picture media are media used in visual learning that provide a series of pictures about something so that the explanation is more concrete than described in words. Through picture series, teachers can translate abstract ideas that are more realistic and easier to stimulate students' imagination.

One of the media that can be used for learning Indonesian according to Handayati, et al, (2013) is song media, this media is a tool that uses magnetic tape in the form of a cassette or compact disk that only produces audio without images. These tapes and compact discs must be played using an audio cassette or CD player. In the learning process, media songs in the form of song lyrics that are played to students are used as learning aids in writing short stories. This song media is classified as audio media because it uses sound and vibrations from magnetic devices to convey messages.

In addition to those described above, other types of media are audiovisual media. According to Hartidini, et al, (2018) audiovisual media are media that have sound and image elements. This media has a better type of ability, because it includes both types of media, namely audio media and visual media. These two media are combined into a learning platform that makes it easier to understand the subject matter. According to Arsyad (in Hartidini et al, 2018) audiovisual-based media is visual media that contains the use of additional sound to produce it. Sudjana and Rivai (in Hartidini et al, 2018) state that audiovisual media are several pieces of equipment used by teachers in conveying concepts, ideas and experiences that are captured by the human senses of sight and hearing.

This audiovisual media has several advantages. This was conveyed by Arysad (in Mulyani, et al, 2019) that there are six advantages of audiovisual media, namely, (1) it can complement the basic experiences of students when they read, discuss, practice, and others; (2) can display impressions that are a substitute for the natural environment and can even show objects that are not normally visible; (3) can describe a process accurately that can be presented repeatedly; (4) encourage and increase motivation; (5) can shape students' attitudes and behavior; (6) contains values that can invite thought and discussion in groups of students, (7) can be used in large groups or small groups, heterogeneous groups or individuals, and (8) can shorten the picture of normal events (efficient in terms of time).

Associated with all the media that have been described. These various media can be used to support Indonesian language learning activities, including for junior high school students. Through a variety of existing learning media, it is easier for junior high school students to access information about education. Students who use media for learning needs can increase the effectiveness of the learning process. At this stage the existing technology has achieved the appropriate objectives by students. However, the reality in the field is that the media for learning Indonesian has not been fully used effectively for junior high school students. Difficult access factors, costs, and so on make the use of learning media not fully used by students. 
This is in line with the questionnaire that has been distributed to thirty SMP/MTSN students from various regions who are respondents. There are 23 students of SMP 8 Padang who became respondents, 1 student of MTSN 42 Jakarta who became respondents, 1 student of SMP 4 Padang who became respondents, 1 student of SMP 91 Jakarta who became respondents, 1 student of MTSN 2 Pesisir Selatan who became respondents, 1 student of SMP Muh 1 Godean Yogyakarta was the respondent, 1 SMP 2 Payakumbuh student was the respondent, and 1 SMP 1 Yogyakarta student was the respondent. Based on the statements submitted, each of them got the following results.

The first statement, "Teachers use media in learning Indonesian" $70 \%$ agree, $26.7 \%$ strongly agree, and $3.3 \%$ disagree. The second statement, "The learning media you use is hardware" $73.3 \%$ agree, $16.7 \%$ disagree, $6.7 \%$ strongly agree, and 3.3\% disagree. The third statement, "The learning media you use is software" $76.7 \%$ agree, $13.3 \%$ strongly agree, $6.7 \%$ disagree, and $3.3 \%$ disagree. The fourth statement, "Learning media makes it easier for you to understand Indonesian language subject matter" $73.3 \%$ agree, 20\% strongly agree, and $6.7 \%$ disagree. The fifth statement, "You prefer the use of learning media in the form of hardware" $63.3 \%$ agree, $26.7 \%$ disagree, $10 \%$ strongly agree. The sixth statement, "You prefer the use of learning media in the form of software" $66.7 \%$ agree, $20 \%$ disagree, $13.3 \%$ strongly agree. The seventh statement, "The use of learning media affects your understanding of Indonesian language learning materials" $70 \%$ agree, $30 \%$ strongly agree. The eighth statement, "Your learning results are better if learning uses a variety of media" $76.7 \%$ agree, $20 \%$ strongly agree, and 3.3\% disagree. The ninth statement, "There are obstacles in using media in learning Indonesian" 50\% disagree, $43.3 \%$ agree, and $6.7 \%$ strongly agree. The tenth statement "The use of learning media from teachers is very limited" $66.7 \%$ agree, $30 \%$ disagree, and 3.3\% disagree.

Through the results of the questionnaire that has been filled out by SMP/MTSN students, it can be explained that learning Indonesian by using learning media has been carried out by the teacher. The learning media used by students is software rather than hardware. This is evidenced by the results of using software as much as $76.7 \%$ while the results of hardware use $73.3 \%$. Students who filled out the questionnaire agreed that the learning media made it easier for them to understand Indonesian language learning materials. This is evidenced by $73.3 \%$ agree. Students agree that the use of learning media in the form of software is preferred. This is evidenced by $66.7 \%$ agree while $63.3 \%$ choose to like learning media with hardware. Students who filled out the questionnaire agreed that the use of learning media affected their understanding of Indonesian language learning materials. This is evidenced by $70 \%$ choosing the agree option. $76.7 \%$ chose the option to agree with the statement that student learning outcomes are better if learning uses a variety of media. The results for the statement that there are obstacles to the use of media in Indonesian language learning are 50\% agree. Finally, $66.7 \%$ of students agree that the use of learning media from teachers is very limited.

It can be concluded that the media has been used for learning Indonesian, the use of learning media commonly used and favored by students is software. Learning media helps students in understanding Indonesian language learning, of course this affects student learning outcomes. Although learning media have been used to improve students' understanding, their use is still very limited. The learning media has not yet found its full function to support the student learning process. Suggestions for the future, it is hoped that the use of learning media for Indonesian language learning will be improved, diverse media will certainly make it easier for students to understand the material. However, the exploration of the use of this media must be 
improved by teachers for Indonesian language learning materials so that the function of learning media can be fully achieved.

\section{Reference :}

Fitri, Y., Syahrul, R., \& Tamsin, A. C. (2016). Pengaruh Model Pembelajaran Kooperatif Tipe Think Write Berbantuan Media Gambar terhadap Keterampilan Menulis Karangan Argumentasi Siswa Kelas X SMA Negeri 5 Padang. Jurnal Bahasa dan Sastra Indonesia, $5(2), 548-555$.

Handayanti, W., Syahrul R., \& Afnita. (2013). Keefektifan Penggunaan Media Lagu dalam

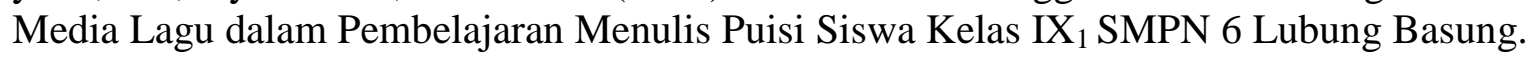
Jurnal Pendidikan Bahasa dan Sastra Indonesia, 1(2), 164-240.

Hartidini, S., Syahrul, R., \& Ratna, E. (2018). Pengaruh Pembelajaran Strategi Inkuiri Berbantuan Media Audiovisual Terhadap Keterampilan Menulis Karangan Argumentasi Ssiwa Kelas X SMA Negeri Lengayang Kabupaten Pesisir Selatan. Jurnal Pendidikan Bahasa dan Sastra Indonesia, 1(7), 63-69.

Hizati, A., Syahrul, R., \& Arief, E. (2018). Pengaruh Model Problem Based Learning Berbantuan Media Gambar Berseri terhadap Keterampilan MenulisTeks Eksplanasi Siswa Kelas VIII SMP Negeri 12 Padang. Jurnal Pendidikan Bahasa dan Sastra Indonesia, 7(1), 183-190.

Jaya, S., Syahrul, R., Ermanto. (2013). Peningkatan Keterampilan Menulis Puisi Melalui Media Gambar Siswa Kelas X. 1 SMA Negeri 2 Kota Sungai Penuh. Bahasa, Sastra, dan Pembelajaran, 1(2), 87-95.

Mulyadi, Atmazaki, Syahrul, R, \& Agustina. (2018). The Development of Interactive Multimedia E-Module on Indonesia Language Course. In: $1^{\text {st }}$ International Conference on Innovation in Education (ICoIE 2018) (pp.291-295). Atlantis Press.

Mulyani, R., Syahrul R. (2019). Pengaruh Model Pembelajaran Kooperatif Tipe Think Talk Write (TTW) Berbantuan Media Audiovisual terhadap Keterampilan Menulis Teks Persuasi Siswa Kelas VIII SMP Negeri 8 Padang. Jurnal Pendidikan Bahasa dan Sastra Indonesia, 8(3), 374-382.

Novelti, Syahrul, R.. Ermanto, \& Agustina. (2018). Developing an Instructional Model Assisted Audio Visual Media. Advances in Social Science, Education and Humanities Research, Volume 263.

Ramadhan, S., Sukma, E., \& Indriyani. (2019). Teacher Competence in Utilizing Digital Media Literacy in Education. Journal of Physics: Conference Series.

Yulia D., A, Syahrul, R, \& Ratna, E. (2012). Peningkatan Keterampilan Menulis Argumentasi Siswa Kelas X Smk N 1 Batusangkar. Pendidikan Bahasa dan Sastra Indonesia, 1(1), 339345. 
